\title{
Knowledge and Attitude of Pregnant Women Related to Hyperemesis Gravidarum at Jagong Health Center, Jagong Jeget District, Central Aceh Regency in 2021
}

\author{
Nova Ratna Dewi ${ }^{1^{*}}$, Sri Wahyuni M.S. ${ }^{1}$, Hidayana ${ }^{1}$ \\ ${ }^{1}$ Diploma of Midwifery, Central Aceh Health Polytechnic, Aceh, Indonesia
}

\section{A R T I C L E I N F O \\ Keywords: \\ Knowledge \\ Hyperemesis gravidarum \\ Pregnancy \\ Nutrition \\ *Corresponding author: \\ Nova Ratna Dewi \\ E-mail address:

novaratnadewi675@gmail.com

All authors have reviewed and approved the final version of the manuscript.

https://doi.org/10.37275/bsm.v6i4.483

\begin{abstract}
A B S T R A C T
Background. Continuous hyperemesis gravidarum can cause a lack of food and fluids that can affect fetal development. Lack of food and fluids or dehydration has a bad effect on the unborn child as well as on the mother herself. This study aims to determine the extent of knowledge and attitudes of pregnant women to the incidence of hyperemesis gravidarum in the working area of the Jagong Health Center, Jagong Jeget District, Central Aceh Regency in 2021. Methods: This type of research is descriptive, the sample of this research is pregnant women in the working area of the Jagong Health Center totaling 30 people. Data were collected and measured using a questionnaire. Results: Mother's knowledge about hyperemesis gravidarum has a good level of knowledge as many as 15 respondents $(50 \%)$, attitudes of pregnant women with hyperemesis gravidarum have a level of a positive attitude as much as $28(80 \%)$, while knowledge of pregnant women and attitudes of pregnant women with hyperemesis gravidarum as much as 15 (50\%). Conclusion: It is expected that pregnant women should be able to increase their knowledge and seek more information from health workers and media mass to increase the knowledge of pregnant women about health, especially regarding the incidence of hyperemesis gravidarum.
\end{abstract}

\section{Introduction}

Pregnancy is a unique and mysterious event. For every married couple, every pregnancy is expected to end safely and in prosperity both for the mother and for the fetus, therefore quality maternal health services are very important and all women are expected to receive health services. Nausea and vomiting are symptoms that are normal and often found in the first trimester of pregnancy, nausea usually occurs in the morning but can also occur at any time and night. These symptoms occur approximately 6 weeks after the first day of menstruation ends and last for approximately 10 weeks. ${ }^{1}$

Hyperemesis gravidarum is defined as that which during pregnancy can lead to electrolyte imbalance or nutritional deficiency and incident weight loss. This condition is about 3.5 per 1000 births, although most one in every 1000 pregnant women will undergo hospitalization.2,3 Hyperemesis gravidarum generally goes away on its own (self-limiting) but this condition is common and tends to recur in subsequent pregnancies. 4

Nausea and vomiting occur in $60-80 \%$ primi and $40-$ 
$60 \%$ multigravida, one of which is a thousand pregnancies, these symptoms become more severe, this feeling of nausea is caused by the increase in the hormone estrogen and HCG in the serum, the physiological effect of this hormone increase is not clear. It may be due to a reduced central nervous system or stomach. In general, women can adjust to this situation lasting up to 4 months. Daily work becomes disrupted and the general condition becomes worse, this condition is called hyperemesis gravidarum. Complaints of symptoms and physiological changes determine the severity of hyperemesis gravidarum. ${ }^{5}$

Pregnant women experience nausea and vomiting that can cause the body to become weak, pale face, and the frequency of urination decreases drastically, this is what is called hyperemesis gravidarum. The cause of hyperemesis gravidarum is not known for certain, but there are prodis position factors including primigravida, molesidatidosa, multiple pregnancies. ${ }^{5,6}$

Continuous hyperemesis can lead to a lack of food and fluids that can affect fetal development. Lack of food and fluids or dehydration has a bad effect on the unborn child as well as on the mother herself. 7,8

Hyperemesis gravidarum often occurs in pregnant women. Theoretically, pregnant women with higher education tend to pay more attention to self and family health, pregnancy history factors. ${ }^{9}$ The most common predisposition is multiple pregnancies. The high frequency of malformations and multiple pregnancies raises the suspicion that hormonal factors play a role because in both conditions the hydroxide hormone is formed in excess, a history of maternal disease that causes hyperemesis gravidarum, other factors such as hyperthyroidism, diabetes. Center, Jagong Jeget District, Central Aceh Regency in 2021

\section{Methods}

This type of research is a descriptive design that aims to find out the knowledge and attitude of pregnant women towards hyperemesis gravidarum at Jagong Health Center, Jagong Jeget District, Central Aceh Regency.

The research was conducted at the Jagong Health Center, Jagong Jeget District, Central Aceh Regency because it is one of the referral health centers from villages in Jagong Jeget District so it can be estimated that it will be easy to obtain. The study was conducted in September 2021. The population in this study were all pregnant women who visited the health center as many as 145 people in Central Aceh Regency in 2021.

\section{Results}

Table 1. Frequency distribution of respondents based on the knowledge of pregnant women about hyperemesis gravidarum at the Jagong Health Center, Jagong Jeget District, Central Aceh Regency in 2021

\begin{tabular}{|c|c|c|c|}
\hline Number & Category & Frequency & Presentation \\
\hline 1. & Good & 15 & $50 \%$ \\
\hline 2. & Enough & 9 & $30 \%$ \\
\hline 3. & Less & 6 & $20 \%$ \\
\hline & Total & 30 & $100 \%$ \\
\hline
\end{tabular}

The results showed that the frequency of pregnant women experiencing hyperemesis gravidarum at the
Jagong Health Center, Jagong Jeget District, Central Aceh Regency is good numbered 15 people (50\%). 
Table 2. Distribution of attitudes of pregnant women with hyperemesis gravidarum at the Jagong Health Center, Jagong Jeget District, Central Aceh Regency in 2021

\begin{tabular}{|c|c|c|c|}
\hline Number & Category & Frequency & Presentation \\
\hline 1. & Positive & 28 & $80 \%$ \\
\hline 2. & Negative & 2 & $20 \%$ \\
\hline & Total & 30 & $100 \%$ \\
\hline
\end{tabular}

The data above it shows that the majority of pregnant women's attitudes at the Jagong Health Center, Jagong Jeget District, Central Aceh Regency are positive, totaling 28 people (80\%) and the minority being at negative which amounted to 2 people $(20 \%)$.

Table 3. Cross-tabulation of knowledge level and attitude of pregnant women with hyperemesis gravidarum at Jagong Health Center, Jagong Jeget District, Central Aceh Regency

\begin{tabular}{|c|c|c|c|c|c|c|}
\hline \multirow{3}{*}{$\begin{array}{c}\text { Level of } \\
\text { Knowledge }\end{array}$} & \multicolumn{4}{|c|}{ Attitude } & \multirow{2}{*}{\multicolumn{2}{|c|}{ Total }} \\
\hline & \multicolumn{2}{|c|}{ Negative } & \multicolumn{2}{|c|}{ Positive } & & \\
\hline & Frequency & $\%$ & Frequency & $\%$ & Frequency & $\%$ \\
\hline Enough & 0 & 0 & 9 & 2.7 & 9 & 2.7 \\
\hline Good & 5 & 1.5 & 10 & 4.5 & 20 & 6.0 \\
\hline
\end{tabular}

The results showed that of the 30 respondents from 6 people with less knowledge the six of them had a positive attitude and nothing negative. Of the 9 people who have sufficient knowledge, none have negative traits. and 10 well-informed people all had positive attitudes. Increased knowledge will give the mother a positive attitude about the incidence of hyperemesis gravidarum.

\section{Discussion}

Based on the results of the study, it was found that the frequency of Gravida Pregnant Women Experiencing Hyperemesis Gravidarum at the Jagong Health Center, Jagong Jeget District, Central Aceh Regency is good numbered 15 people (50\%). This means that respondents do not fully understand the definition and need for iron tablets for pregnant women when viewed from an educational perspective, pregnant women do not understand the definition and need for iron tablets for pregnant women because the majority of pregnant women are educated in the working area of the Jagong Health Center, Jagong Subdistrict, Central Aceh Regency, which is the majority of SMA, and when viewed in terms of work the majority of pregnant women's work in the working area of the Jagong Health Center, Jagong District, Central Aceh Regency is Housewives (IRT) so that pregnant women do not fully know about the definition and need for iron for pregnant women. To overcome this, it is necessary to provide counseling and information both from print media such as books and other media and it is hoped that respondents do not ignore and ignore existing information, especially regarding the definition and need for iron for pregnant women.

The majority of pregnant women's attitudes at the Jagong Jeget Health Center, Central Aceh Regency, were positive, amounting to 28 people $(80 \%)$ and the minority was negative, amounting to 2 people $(20 \%)$. The knowledge of pregnant women is in the sufficient category, but the mother's attitude towards the 
consumption of iron tablets is in a good category, this shows that the mother's knowledge does not affect her attitude in consuming iron tablets. Attitude is a reaction or response of someone who is still close to a stimulus or object. In this case, the mother's attitude in consuming iron tablets is good, this is also influenced by the age and education of the respondents, the majority of whom are high school graduates who can understand and digest the information provided. ${ }^{8}$

According to Widayana et al., attitude is the result of a person's reaction or response who is still closed to a stimulus or object. If someone has a positive attitude, then someone can accept, respond, appreciate, and be responsible for certain materials or objects. But on the contrary, if the action is not realized with a good and positive attitude then the action will be refused to the object under study. ${ }^{9}$

The results showed that of the 30 respondents from 6 people with less knowledge, the 6 had a positive attitude and none of them were negative. Of the 9 people who have sufficient knowledge, none have negative traits. and 10 well-informed people all had positive attitudes. Increased knowledge will give the mother a positive attitude about the incidence of hyperemesis gravidarum.

\section{Conclusion}

Knowledge of pregnant women with hyperemesis gravidarum has a good level of knowledge of $50 \%$. The attitude of pregnant women with hyperemesis gravidarum has a positive attitude rate of $80 \%$. Knowledge of pregnant women and attitudes of pregnant women with hyperemesis gravidarum as much as $50 \%$.

\section{References}

1. London V, Grube S, Sherer DM, Abulafia O. Hyperemesis gravidarum: A review of recent literature. Pharmacology. 2017; 100: 161-71.

2. Health office of Nangroe Aceh Darussalam Province. NAD Province Health Profile 2020. 2020.

3. Health Office of Central Aceh Regency. Central Aceh District Health Profile 2020. 2020.

4. Susanti NMD, Lainsamputty F, Ilestari V. Stress with hyperemesis gravidarum in pregnant women. J Scientific Health Sandi Husada. 2021; 10(2): 62-6.

5. Wegrzyniak LJ, Repke JT, Urai SH. Treatment of hyperemesis gravidarum. Rev Obs Gyn. 2012; 5(2): 78-84.

6. Boelig RC, Barton SJ, Saccone G, Kelly AJ, Edwards SJ, et al. Interventions for treating hyperemesis gravidarum: a Cochrane systematic review and meta-analysis. J Matern Fetal Neonatal Med. 2018; 31(18): 2492-505.

7. Mamesah I, Loho M, Suparman E. Relationship between BMI and B-HCG levels with hyperemesis gravidarum in Manado, Indonesia. Obs Gin Magazine. 2019; 27(3): 108-13.

8. Fejzo MS, Trovik J, Grooten IJ, Sridharan K, Rooseboom TJ, et al. Nausea and vomiting of pregnancy and hyperemesis gravidarum. Nature Rev Dis Primers. 2019; 62(5).

9. Widayana A, Megahana IW, Kemara KP. Diagnosis and management of hyperemesis gravidarum. J Medika Udayana. 2013; 2(4): 658-6 